\title{
FOTOTERAPI 405NM BLUE LIGHT LASER SEBAGAI ALTERNATIF TERAPI GONORE KOINFEKSI KLAMIDIASIS RESISTEN ANTIBIOTIK
}

\author{
Alfiani Zukhruful Fitri $\mathbf{R},{ }^{1}$ Clara Alverina, ${ }^{1}$ \\ ${ }^{1}$ Program Studi Kedokteran, Fakultas Kedokteran, Universitas Airlangga, Surabaya
}

\begin{abstract}
ABSTRAK
Korespondensi:

Alfiani Zukhruful Fitri

Email author:

alfiani.zukhruful.fitri-

2018@fk.unair.ac.id

Riwayat Artikel

Diterima: 8 Maret 2021

Selesai revisi: 25 Juni 2021

DOI :

10.53366/jimki.v9i1.301

Pendahuluan: Gonore atau kencing nanah merupakan infeksi menular seksual (IMS) yang disebabkan oleh bakteri Neisseria gonorrhoeae, umumnya menyerang mukosa genital. Insidensi gonore tidak sedikit, WHO menyebutkan 87 juta kasus baru di tahun 2016. Adapun kasus koinfeksi Chlamydia trachomatis sekitar 10-40\%. Menurut WHO 2018, disebutkan bahwa $70 \%$ negara melaporkan resistensi antimikroba karena N. gonorrhoeae. Tidak hanya itu, belakangan juga ditemukan resistensi sefalosporin generasi ketiga di 10 negara.

Metode: Studi literatur ini ditujukan untuk mengetahui potensi terapi alternatif gonore koinfeksi klamidiasis yang resisten antibiotik. Sitasi yang digunakan berasal dari jurnal ilmiah di Google Scholar, PubMed, dan publikasi WHO dari tahun 2015-2020.

Pembahasan: Antimicrobial blue light (aBL) merupakan jenis terapi untuk mengendalikan infeksi bakteri yang resisten antibiotik didasarkan pada penggunaan cahaya. Mekanisme aBL dengan panjang gelombang 405 $\mathrm{nm}$ adalah menginaktivasi mikroba melalui efek sitotoksik dan genotoksik melalui fotosensitizer endogen pada mikroba. Hal tersebut kemudian menyebabkan kerusakan membran sel serta inaktivasi faktor virulensi bakteri, baik $N$. gonorrhoeae dan $C$. trachomatis.

Simpulan: Fototerapi $405 \mathrm{~nm}$ Blue Light Laser dapat menjadi alternatif terapi non farmakologis untuk pengobatan gonore baik infeksi tunggal maupun disertai koinfeksi klamidiasis. Adapun kelebihannya antara lain, mudah digunakan, tidak invasif, membutuhkan durasi yang cukup singkat, memiliki selektivitas yang tinggi sehingga tidak merugikan sel epitel vagina, dan tidak ada resistensi terhadap penggunaan fototerapi ini.
\end{abstract}

Kata Kunci: Fototerapi 405nm, Neisseria Gonorrhoeae

\section{NM BLUE LIGHT LASER PHOTOTHERAPY AS AN ALTERNATIVE THERAPY FOR ANTIBIOTICS-RESISTANT GONORRHEA-CHLAMYDIASIS COINFECTION}

\begin{abstract}
Background: Gonorrhea is a sexually transmitted infection (STI) caused by Neisseria gonorrhoeae, which generally attacks genital mucosa. The incidence of gonorrhea is pretty high, WHO mentioned 87 million new cases in 2016. The co-infection with Chlamydia trachomatis is around 10-40\%. According to WHO 2018, 70\% of countries reported antimicrobial resistance to $N$. gonorrhoeae. Besides, third-generation cephalosporin resistance has also been found in 10 countries.
\end{abstract}




\begin{abstract}
Methods: This literature study aims to determine the potential alternative therapy for antibiotic-resistant gonorrhea with chlamydia co-infection. The source used in this literature comes from scientific journals at Google Scholar, PubMed, and WHO publications from 2015-2020.

Discussion: Antimicrobial blue light $(a B L)$ is a type of therapy to control antibioticresistant bacterial infections based on the use of light. The mechanism of aBL with a wavelength of $405 \mathrm{~nm}$ is by inactivating microbes through cytotoxic and genotoxic effects through endogenous photosensitizers on microbes that cause damage to cell membranes and inactivation of bacterial virulence factors, both N. gonorrhoeae, and C. trachomatis.

Conclusion: Phototherapy $405 \mathrm{~nm}$ Blue Light Laser can be an alternative nonpharmacological therapy for the treatment of gonorrhea, both single infection and chlamydial coinfection. The advantages, are easy to use, non-invasive, require a fairly short duration, have high selectivity so that it does not harm vaginal epithelial cells, and there is no resistance to this phototherapy.
\end{abstract}

Keywords: 405nm phototherapy, Neisseria gonorrhoeae

\section{PENDAHULUAN}

Gonore atau dikenal sebagai kencing nanah merupakan infeksi menular seksual (IMS) yang disebabkan oleh bakteri Neisseria gonorrhoeae, umumnya menyerang mukosa genital atau mukosa serviks..$^{[1]}$ Insidensi gonore semakin meningkat, menurut World Health Organization (WHO) diperkirakan terdapat 87 juta kasus baru pada tahun 2016. ${ }^{[2]} \mathrm{Hal}$ tersebut sesuai dengan estimasi global yang memperkirakan terdapat 376,4 juta kasus IMS baru pada tahun 2016 dengan presentasi gonore sebagai IMS tertinggi kedua yang disebabkan oleh bakteri setelah klamidiasis. ${ }^{[3]}$

Di Indonesia sendiri, belum terdapat data pasti mengenai prevalensi gonore secara keseluruhan.

Berdasarkan penelitian di Sexually Transmitted Disease Clinic's of Ciracas Primary Health Care Jakarta pada tahun 2010, didapatkan prevalensi IMS dari seluruh sampel adalah $34,2 \%$, terdiri dari gonore $22,4 \%$, sifilis $7,1 \%$ dan HIV $4,7 \%{ }^{[4]} \quad$ Sedangkan berdasarkan penelitian di klinik Anggrek UPT Ubud II, Bali pada bulan Januari-Desember 2016 mengenai IMS dari 273 sampel presentasi gonore adalah $22,3 \%{ }^{\left[{ }^{[5]}\right.}$ Angka tersebut seharusnya menjadi perhatian mengingat gonore dapat menurunkan kualitas hidup seseorang berdasarkan Global Burden of Disease. ${ }^{[6]}$

Infeksi $N$. gonorrhoeae pada pria bersifat simtomatik dan menyebabkan urethritis. $^{[1]}$ Gejala yang muncul diantaranya adanya sekret yang keluar dari uretra, gatal, nyeri saat berkemih, hingga nyeri pada testis atau daerah rektal. ${ }^{[7]}$ Sedangkan pada wanita, infeksi $N$. gonorrhoeae seringkali tidak bergejala (asimtomatik) sehingga bisa luput dari perhatian. ${ }^{[1]}$ Jika bergejala, gambaran klinis pada wanita meliputi keputihan, disuria, dispareunia, perdarahan uterus abnormal, nyeri perut bagian bawah dan/atau rektal. ${ }^{[7]}$ WHO juga menyebutkan gonore yang tidak diobat juga dapat menyebabkan komplikasi seperti Pelvic Inflammatory Disease (PID), yang dapat berakibat pada kemandulan, kehamilan ektopik, dan nyeri kronis pada wanita. ${ }^{[1,2]}$

Penderita gonore biasanya juga mengalami koinfeksi dengan Chlamydia trachomatis sekitar $10-40 \%$ dari seluruh kasus gonore..$^{[8]}$ Koinfeksi ini dalam banyak kasus, dikaitkan dengan meningkatnya kejadian dan/atau risiko infeksi ulang $C$. trachomatis atau $N$. gonorrhoeae saat diuji kembali setelah 6 minggu dan 6 bulan..$^{[9]}$ Oleh karenanya beberapa regimen pengobatan yang digunakan dalam kasus gonore juga ditambah untuk terapi klamidiasis.

Pada praktik klinis, pengobatan gonore hanya berdasarkan terapi antibiotik empiris. Penegakan diagnosis gonore pun hanya berdasarkan pemeriksaan mikroskopis menggunakan pewarnaan gram atau metilen blue, sedangkan tes kepekaan antimikroba tidak rutin dilakukan. ${ }^{[10]}$ Sedangkan satu 
kendala dalam program

penanggulangan gonore adalah kemampuan bakteri $N$. gonorrhoeae menjadisuperbug yang

mengembangkan resistansi terhadap beberapa antibiotik. Oleh karena itu, terapi gonore yang saat ini digunakan memiliki pilihan antibiotik yang terbatas, sedangkan resistensi antimikroba yang semakin meluas menjadi sebuah kekhawatiran bahwa gonore menjadi tidak bisa diobati di masa mendatang. Sehingga dibutuhkan solusi alternatif yang lebih menjanjikan seperti fototerapi dengan Antimicrobial Blue Light (405 $\mathrm{nm})$ Laser dalam terapi dan eradikasi gonore, baik infeksi tunggal atau koinfeksi dengan klamidiasis.

\section{METODE}

Tinjauan pustaka ini disusun dengan mencari, mengumpulkan, dan menganalisis berbagai studi dalam jurnal ilmiah yang meneliti pilihan pengobatan terkini dan di masa mendatang untuk pasien gonore dengan koinfeksi klamidiasis resisten obat. Kata kunci yang digunakan dalam pencarian mencakup ("Gonorrhea" OR "GO" OR "Neisseria gonorrhoeae") AND ("Chlamydiasis" OR "Chlamydia trachomatis") AND ("Antimicrobial blue light" OR "aBL" OR "blue light therapy" OR "photodynamic therapy). Sumbersumber yang digunakan disitasi dari Google Scholar, PubMed, dan Scopus yang diterbitkan antara 2011-2020. Kriteria inklusi yang digunakan dalam tinjauan ini adalah (1) penelitian yang melakukan uji coba in vitro aBL $405 \mathrm{~nm}$ terhadap $N$. gonorrhoeae dan $C$. trachomatis, (2) artikel asli, (3) penelitian yang melaporkan efektivitas paparan radiasi dan keefektivitasannya dalam mengeradikasi bakteri. Kriteria eksklusi yang digunakan adalah (1) studi tidak dalam bahasa Inggris, (2) abstrak, ulasan, laporan kasus, atau bagian buku. Literatur yang diperoleh dari pencarian database akan disaring terlebih dahulu berdasarkan judul dan abstrak. Literatur potensial akan dinilai lebih lanjut dengan membaca teks lengkapnya. Pada akhirnya, kami menyimpulkan 3 artikel utama [Wang., Et al, (2019); Ferrer-Espada., Dkk,
(2020); Wasson., Et al, (2012)] untuk dimasukkan dalam review ini dan 23 artikel pendukung lainnya.

\section{PEMBAHASAN}

\subsection{Resistensi Antimikroba pada $N$. Gonorrheae}

Resistensi mikroba terhadap berbagai antibiotik masih menjadi isu dunia kesehatan hingga saat ini. Berdasarkan Report on Global Sexually Transmitted Infection Surveillance 2018 oleh WHO, disebutkan bahwa $70 \%$ negara melaporkan resistensi antimikroba (AMR) terhadap $N$. gonorrhoeae. Resistensi antimikroba terhadap gonore sudah meluas hingga mencakup antibiotik penicilin, golongan makrolida (termasuk azithromicin), sulfonamida, kombinasi trimetoprim dan quinolon, serta baru-baru ini dilaporkan adanya beberapa strain yang resistensi terhadap seftriakson. [2]

Di Indonesia pada penelitian $2012 \mathrm{di}$ Jakarta Timur, Tangerang, dan Palembang dari 179 isolat $N$. gonorrhoeae yang berhasil dikultur dan diuji kepekaan antibiotiknya didapatkan hasil resistensi yang cukup tinggi terhadap penisilin, tetrasiklin, dan kuinolon. ${ }^{[11]}$ Tidak hanya itu, pada penelitian ini ditemukan adanya penurunan kepekaan pada sefiksim $(1,7 \%)$ dan seftriakson $(1,1 \%)$. Keduanya merupakan pilihan pengobatan dalam pedoman nasional IMS dan merupakan rekomendasi lini terakhir untuk monoterapi berdasarkan WHO. $[2,11,12]$

Penurunan kepekaan terhadap sefalosporin generasi ketiga semakin tersebar luas dan dilaporkan terjadinya kegagalan pengobatan oleh 10 negara. ${ }^{[2]}$ Dalam penelitian juga disebutkan strain yang resisten seftriakson saat ini menyebar di seluruh dunia, terutama terkait perjalanan ke Asia. ${ }^{[13]}$ Resistensi bakteri terjadi semakin cepat karena penggunaan antibiotik yang luas dan tidak rasional dan hal ini menjadi permasalahan karena menurunkan efektivitas pengobatan dan memberikan prognosis yang lebih buruk bagi pasien. ${ }^{[14]}$

$$
\text { Berdasarkan }
$$

Kementerian

Kesehatan RI (2016), rekomendasi 
terapi untuk gonore adalah dengan antibiotika. Lini pertamanya adalah Cefixime $400 \mathrm{mg}$, dosis tunggal, peroral dan lini keduanya bisa dengan kanamisin $2 \mathrm{~g}$, injeksi intramuskuler, dosis tunggal atau Ceftriaxone $250 \mathrm{mg}$, injeksi intramuskuler, dosis tunggal. Dahulunya antibiotik ciprofloxacin dan ofloxacin juga digunakan sebagai terapi untuk gonore, namun telah menunjukkan adanya angka resistensi yang tinggi dibeberapa kota sehingga tidak dianjurkan lagi oleh Kementerian Kesehatan RI. Rekomendasi terapi untuk klamidiasis adalah Azithromycin $1 \mathrm{~g}$, dosis tunggal, peroral atau Doksisiklin 2x100mg/hari, peroral, selama 7 hari. Terapi dengan antibiotika saat ini masih menjadi pilihan dan dapat mengatasi infeksi gonore dan klamidiasis, namun sudah banyak antibiotik yang tidak lagi dapat digunakan karena terjadi resistensi. Pilihan antibiotik semakin sedikit dan harus digunakan secara bijak dan rasional. Agar resistensi terhadap antibiotik ini tidak terus berkembang, terapi gonore dengan fototerapi antimicrobial Blue Light (aBL) dengan panjang gelombang $405 \mathrm{~nm}$ dapat digunakan sebagai suatu alternatif terapi non farmakologis untuk gonore dengan/ tanpa koinfeksi dengan klamidia karena tidak invasif dan tidak ada resistensi terhadap fototerapi ini.

\subsection{Potensi 405nm Blue Light Sebagai Fototerapi Gonore}

Sebuah solusi dikembangkan beberapa tahun terakhir sebagai alternatif terapi tanpa antibiotik untuk mengatasi infeksi mikroorganisme, salah satunya adalah terapi dengan antimicrobial Blue Light. ${ }^{[15]}$ Antimicrobial Blue Light (aBL) merupakan jenis terapi untuk mengendalikan infeksi bakteri yang resisten antibiotik didasarkan pada penggunaan cahaya, khususnya pada panjang gelombang biru (400-470 nm) karena dapat menurunkan viabilitas berbagai spesies bakteri walau dengan radiasi yang rendah. ${ }^{[16,17]}$

Cahaya biru dengan panjang gelombang 400-470nm secara intrinsik bersifat antimikroba tanpa memerlukan fotosensitizer eksogen tambahan (Dai,
2012). Inaktivasi fotodinamik dari sel bakteri terjadi akibat fotoeksitasi porfirin intraseluler bakteri tersebut oleh cahaya biru yang menyebabkan terbentuknya ROS (spesies oksigen reaktif sitotoksik), terutama oksigen singlet $\left({ }^{1} \mathrm{O}_{2}\right) .{ }^{[18,21]}$ Dari berbagai penelitian untuk $N$. gonorrhoeae dan $C$. trachomatis, panjang gelombang yang efektif dalam mengeradikasi kedua bakteri tersebut adalah $405 \mathrm{~nm} \cdot{ }^{[21,22,23]} \mathrm{Hal}$ ini disebabkan pada panjang gelombang tersebut terjadi eksitasi maksimum porfirin, yang berkorelasi semakin banyak stress oksidatif yang dihasilkan sehingga terjadi kerusakan membrane hingga kerusakan DNA bakteri..[18] Tidak hanya itu, cahaya biru juga selektif membunuh bakteri tanpa merusak sel manusia, sehingga lebih aman daripada penggunaan sinar UV. ${ }^{[24]}$

Mekanisme kerja aBL memang belum dapat dipahami seluruhnya, tetapi beberapa hipotesis menjelaskan bahwa aBL akan menginaktivasi mikroba melalui efek sitotoksik dan genotoksiknya. ${ }^{[15]}$ Efek sitotoksik dan genotoksik terjadi melalui rangsangan $\mathrm{aBL}$ terhadap fotosensitizer endogen pada sel mikroba (seperti porfirin, flavin dan/atau NADH) sehingga terjadi fotoeksitasi dan terjadilah pembentukan reactive oxygen species (ROS) yang merusak membran sel serta inaktivasi faktor virulensi bakteri. ${ }^{[19]}$

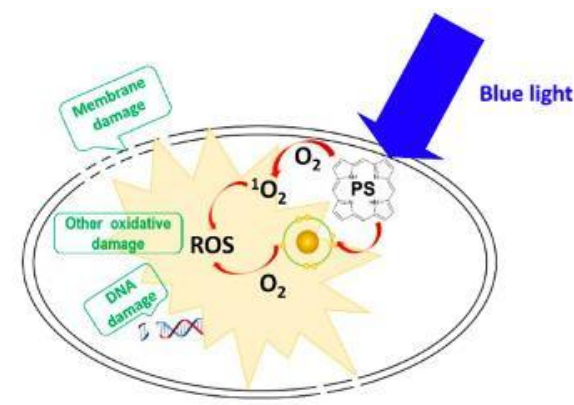

Gambar 1. Mekanisme Kerja aBL. ${ }^{[18]}$

Adapun fotosensitizer endogen yang ditemukan di $N$. gonorrhoeae adalah porfirin (uroporfirin, carboxylporfirin, coproporfirin, protoporfirin) dan flavin (riboflavin, FMN, FAD). Berdasarkan penelitian Wang, 2019 disebutkan bahwa kelebihan aBL $405 \mathrm{~nm}$ adalah dapat mengeksitasi keduanya (baik porfirin dan juga flavin). 
Tidak hanya itu, penelitian ini juga menyimpulkan bahwa $405 \mathrm{~nm}$ aBL menyebabkan fotoeksitasi FAD dan FMN yang menghasilkan oksigen singlet yang lebih banyak daripada panjang gelombang lainnya, sehingga lebih efektif dalam mengeradikasi bakteri. ${ }^{[21]}$

Tabel 1. Inaktivasi Bakteri Dengan Blue Light

\begin{tabular}{|c|c|c|c|}
\hline Sumber Cahaya & Paparan Radiasi & Spesies Bakteri & $\begin{array}{l}\text { Efektivitas } \\
\text { Inaktivasi }\end{array}$ \\
\hline $\begin{array}{l}\text { LED } 405 \mathrm{~nm} \text { dan } \\
470 \mathrm{~nm}\end{array}$ & $\begin{array}{c}27 \mathrm{~J} / \mathrm{cm}^{2} \text { dan } 54 \\
\mathrm{~J} / \mathrm{cm}^{2}\end{array}$ & N. gonorrhoeae & $\begin{array}{c}\text { 405nm aBL: } 3.12- \\
\log _{10} \text { CFU pada } 27 \\
\mathrm{~J} / \mathrm{cm}^{2} \text { dan }>8-\log _{10} \\
\text { CFU pada } 54 \mathrm{~J} / \mathrm{cm}^{2} \\
470 \mathrm{~nm} \text { aBL: }<1- \\
\log _{10} \mathrm{CFU} \text { pada } 54 \\
\mathrm{~J} / \mathrm{cm}^{2}\end{array}$ \\
\hline LED 405nm & $\begin{array}{c}108 \mathrm{~J} / \mathrm{cm}^{2} \text { untuk } N \text {. } \\
\text { gonorrhoeae, } 216 \\
\mathrm{~J} / \mathrm{cm}^{2} \text { untuk bakteri } \\
\text { lainnya. }\end{array}$ & $\begin{array}{c}\text { A. baumannii, } C \text {. } \\
\text { albicans, } E \text {. Coli, } E \text {. } \\
\text { faecalis, MRSA, N. } \\
\text { gonorrhoeae, } P . \\
\text { aeruginosa, } P . \\
\text { mirabilis }\end{array}$ & $\begin{array}{c}\text { Tidak signifikan: } E \text {. } \\
\text { Coli, } C \text {. albicans } \\
\mathrm{P}<0.01: P . \\
\text { mirabilis, E. faecalis, } \\
\text { MRSA } \\
\mathrm{P}<0.0001: P . \\
\text { aeruginosa, } N . \\
\text { gonorrhoeae, } A . \\
\text { baumannii }\end{array}$ \\
\hline $\begin{array}{l}\text { LED } 405 \mathrm{~nm} \text { dan } \\
\quad 670 \mathrm{~nm}\end{array}$ & $5-20 \mathrm{~J} / \mathrm{cm}^{2}$ & C. trachomatis & $\begin{array}{c}405 \mathrm{~nm}: P<0.005 \\
40 \%-75 \% \\
670 \mathrm{~nm}: \text { tidak } \\
\text { signifikan }\end{array}$ \\
\hline
\end{tabular}

Beberapa penelitian terakhir menemukan efek anti-gonococcal yang signifikan pada aBL dengan menggunakan panjang cahaya 405 nm. ${ }^{[20,21,22]}$ Pada penelitian Wang, 2019 dengan membandingkan panjang cahaya dan berbagai paparan radiasi, didapatkan bahwa $\mathrm{aBL}$ yang paling efektif adalah pada panjang cahaya $405 \mathrm{~nm}$ dengan $54 \mathrm{~J} / \mathrm{cm}^{2}$ yang dapat mereduksi bakteri $>8-\log _{10}$ sehingga eradikasi $N$. gonorrhoeae dapat tercapai. ${ }^{[21]}$ Oleh karena itu, keefektifan fototerapi ini dirasa cukup menjanjikan mengingat waktu yang dibutuhkan juga tidak banyak yaitu sekitar 15 menit dan cukup tinggi mengeradikasi bakteri patogen tersebut.

Berdasarkan penelitian terkait inaktivasi bakteri dengan $405 \mathrm{~nm}$ aBL secara in vitro pada 8 isolat spesies di biofilm didapatkan bahwa $P$. aeruginosa, $N$. gonorrhoeae, A. baumannii adalah yang paling rentan terhadap aBL $405 \mathrm{~nm}$ dengan inaktivasi antara 4-8 $\log _{10}$ CFU setelah $108 \mathrm{~J} / \mathrm{cm}^{2}$ aBL (untuk $N$. gonorrhoeae) atau $216 \mathrm{~J} / \mathrm{cm}^{2}$ (untuk bakteri lainnya). ${ }^{[25]}$

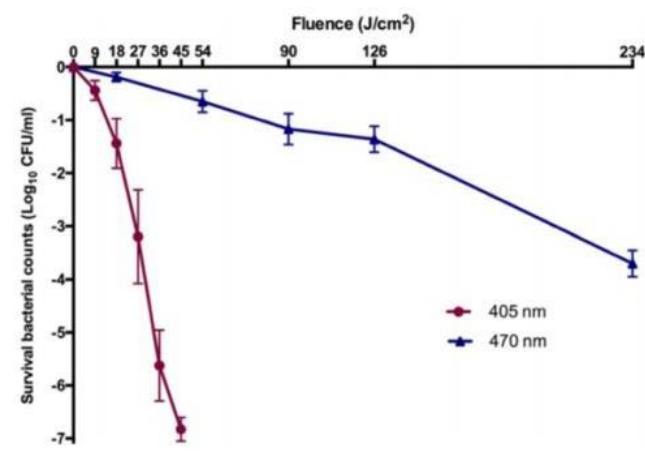

Gambar 2. Inaktivasi Neisseria gonorrhoeae oleh $405 \mathrm{~nm}$ aBL dan 470 $\mathrm{nm}$ aBL ${ }^{[21]}$

Berdasarkan gambar di atas, panjang sinar yang digunakan agar fototerapi ini efektif berdasarkan beberapa penelitian adalah dengan 405 $\mathrm{nm} .{ }^{[20,21,22]}$ Hal tersebut disebabkan 
karena $405 \mathrm{~nm}$ dapat menyerap porfirin dan flavin (riboflavin, flavin mononucleotide/FMN, dan flavin adenine dinucleotide/FAD) secara maksimal yang keduanya diduga merupakan fotosensitizer endogen terbanyak di bakteri, termasuk di $N$. gonorrhoeae. ${ }^{[21]}$

Pada penelitian dengan spektroskopi dan analisis berdasarkan ultra performance liquid chromatography (UPLC), didapatkan hasil $\mathrm{aBL}$ dengan $405 \mathrm{~nm}$ dapat mencetuskan kedua jenis fotosensitizer endogen tersebut di dalam bakteri $N$. gonorrhoeae yang kemudian menyebabkan fototoksisitas ke sel bakteri tersebut. ${ }^{[20]}$ Fototoksisitas tersebut yang memunculkan terbentuknya reactive oxygen species (ROS) dan berlanjut pada kematian sel.

Penelitian in vitro dengan kultur bakteri $N$. gonorrhoeae dan sel epitel vagina manusia (VK2/E6E7) ini juga mendapat kesimpulan bahwa keamanan aBL $405 \mathrm{~nm}$ dapat dibuktikan karena selektivitas $\mathrm{aBL}$ dalam menginaktivasi N. gonorrheae saja dan tidak memberikan efek samping pada sel epitel vagina manusia. Adapun hasil analisis dengan UPLC didapatkan kandungan fotosensitizer endogen yang dapat diinaktivasi oleh $\mathrm{aBL}$ pada sel epitel vagina adalah $>500$ kali lipat lebih rendah daripada mikroba yang patogen, yaitu $N$. gonorrhoeae. ${ }^{[1,22]}$ Sehingga dapat dipastikan bahwa aBL $405 \mathrm{~nm}$ memiliki selektivitas yang tinggi dengan risiko intoksikasi lebih kecil dan tidak merugikan sel inang yang ditempatinya.

Fototerapi yang menggunakan laser daya rendah atau dioda pemancar cahaya (LED) telah terbukti mengurangi rasa sakit dan peradangan kronis, dan meningkatkan regenerasi jaringan melalui mekanisme fotokimia. ${ }^{[26]}$ Oleh karena itu, kelebihan dari terapi antimikroba berbasis cahaya adalah efektivitas eradikasi yang sama sekalipun bakteri sudah mendapatkan resistensi antibiotik.

\subsection{Potensi 405nm Blue Light Sebagai Fototerapi Klamidiasis}

Efek aBL $405 \mathrm{~nm}$ juga ditemukan di Chlamydia trachomatis, yang diteliti dapat mereduksi jumlah CFU bakteri $C$. trachomatis dan mengurangi sekresi IL6 yang merupakan sitokin pro-inflamasi dan berkorelasi dengan klamidiasis kronis. ${ }^{[23]}$

Penelitian pertama dan satusatunya yang menunjukkan penghambatan pertumbuhan klamidia yang disebabkan oleh iradiasi $405 \mathrm{~nm}$ menunjukkan efek penghambatan tergantung dosis yang signifikan pada pertumbuhan $C$. trachomatis setelah paparan aBL $\left(41 \%\right.$ pada $5 \mathrm{~J} / \mathrm{cm}^{2}$ dan $75 \%$ pada $20 \mathrm{~J} / \mathrm{cm}^{2}$ ). Beban bakteri yang berkurang berhubungan dengan konsentrasi IL-6 yang lebih rendah dalam sel HeLa. Oleh karena itu, aBL $405 \mathrm{~nm}$ cukup menjanjikan untuk bersinergis mereduksi gonore dengan koinfeksi klamidiasis. ${ }^{[23]}$

Menariknya, analisis korelasi dalam penelitian Wang pada tahun 2019 menunjukkan tidak terjadinya resistensi aBL oleh $N$. gonorrhoeae bahkan setelah dilakukan paparan sebanyak 15 siklus secara berturut-turut.[22] Hal tersebut tentunya menjawab permasalahan yang ada terkait adanya resistensi penggunaan antibiotik dalam terapi gonore maupun dengan koinfeksi klamidiasis. Selain itu, keuntungan menggunakan aBL $405 \mathrm{~nm}$ adalah mudah, tidak invasif, membutuhkan waktu yang cukup singkat dan memiliki selektivitas yang tinggi sehingga tidak merugikan sel epitel vagina.

\section{KESIMPULAN}

Gonore merupakan penyakit
infeksi menular seksual yang prevalensinya tidak sedikit baik secara global maupun di Indonesia. Manifestasinya pun bermacam-macam mulai dari asimtomatik hingga bisa menyebabkan infertilitas dan gejalanya berbeda antara pria dan wanita, hanya saja ketika tidak ditangani, infeksi yang disebabkan oleh Neisseria gonorrhoeae dapat menjadi masalah serius. Tidak hanya itu, kejadian koinfeksi dengan Chlamydia trachomatis juga sering dijumpai. Masalah tersebut semakin kompleks ketika dilaporkan adanya resistensi beberapa antibiotik terhadap bakteri patogen tersebut. Oleh karena itu, fototerapi dengan Antimicrobial Blue Light (405 nm) Phototherapy merupakan 
sebuah solusi alternatif sebagai terapi non farmakologis untuk pengobatan gonore baik infeksi tunggal maupun disertai koinfeksi klamidiasis. Adapun kelebihannya antara lain, mudah digunakan, tidak invasif, membutuhkan durasi yang cukup singkat, memiliki selektivitas yang tinggi sehingga tidak merugikan sel epitel vagina, dan tidak ada resistensi terhadap penggunaan fototerapi ini.

\section{DAFTAR PUSTAKA}

1. Kumar V, Abbas AK, Aster JC. Robbins Basic Pathology. 10th Ed. Elsevier Health Sciences; 2017.

2. World Health Organization. Gonococcal antimicrobial susceptibility. In Report on global sexually transmitted infection surveillance. Vol. 70, Southern Medical Journal. Geneva; 2018:3337.

3. Rowley J, Hoorn S Vander, Korenromp E, Low N, Unemo M, Abu-Raddad LJ, et al. Chlamydia, gonorrhoea, trichomoniasis and syphilis. Bull World Health Organ. 2019;97(8):548-62.

4. Arum Maujudah S, Susanna D. The incidence of Sexually Transmitted Disease at Ciracas Primary Health Care, East Jakarta. KnE Life Sci. 2019;4(10):96.

5. Chandra Nirmalasari NP. Prevalensi dan Karakteristik IMS di Klinik Anggrek UPT Ubud II pada Bulan Januari - Desember 2016. E-Jurnal Med Udayana. 2018;7:169-75.

6. Vos T, Allen C, Arora M, Barber RM, Brown A, Carter A, et al. Global, regional, and national incidence, prevalence, and years lived with disability for 310 diseases and injuries, 1990-2015: a systematic analysis for the Global Burden of Disease Study 2015.Lancet. 2016;388(10053):1545-602.

7. Piszczek J, St. Jean R, Khaliq Y. Gonorrhea: Treatment update for an increasingly resistant organism. Can Pharm J. 2015;148(2):82-9.

8. Creighton S. Gonorrhoea. BMJ Clin Evid. 2014:1-12.

9. Rose SB, Garrett SM, Stanley J, Pullon SRH. Retesting and repeat positivity following diagnosis of Chlamydia trachomatis and Neisseria gonorrhoea in New Zealand: A retrospective cohort study. BMC Infect Dis. 2017;17(1).

10. Indriatmi W, Prayogo RL, Nilasari $\mathrm{H}$, Suseno LS. Antimicrobial resistance of Neisseria gonorrhoeae in Jakarta, Indonesia: A cross- sectional study. Sex Health. 2020;17(1):9-14.

11. Puspandari N, Sariadji K, Pangerti $R$, Rifati L, Riajuni L, Muna F, et al. Prevalensi dan Pola Resistensi N . gonorrhoeae Terhadap Beberapa Antibiotik pada Wanita Penjaja Seks di Jakarta Timur, Tangerang dan Palembang Tahun 2012 Human Immunodeficiency Virus / Acquired Immunodeficiency penanggulangan gonore adalah kemampu- Healt. J Biotek Medisiana Indonesia. 2016;5(1):57-67.

12. Widaty $\mathrm{S}$, Soebono $\mathrm{H}$, Nilasari $\mathrm{H}$, Listiawan MY, Siswati AS, Triwahyudi D. Panduan praktik klinis bagi dokter spesialis kulit dan kelamin di Indonesia. Vol. 74,Journal of Organic Chemistry. Jakarta: Perhimpunan Dokter Spesialis Kulit dan Kelamin Indonesia; 2017.

13. Unemo M, Golparian D, Eyre DW. Antimicrobial Resistance in Neisseria gonorrhoeae and Treatment of Gonorrhea. Springer Nat. 2019;37-58.

14. Hampton T. Report reveals scope of US antibiotic resistance threat. JAMA - J Am Med Assoc. 2013; 310(16):1661-3.

15. Wang $Y$, Harrington $O D$, Wang $Y$, Murray CK, Hamblin MR, Dai T. In Vivo investigation of antimicrobial blue light therapy for multidrugresistant Acinetobacter baumannii burn infections using bioluminescence imaging. $J$ Vis Exp. 2017;2017(122):1-6.

16. Enwemeka CS. Antimicrobial blue light: An emerging alternative to antibiotics. Photomed Laser Surg. 2013;31(11):509-11.

17. Rupel K, Zupin L, Ottaviani G, Bertani I, Martinelli V, Porrelli D, et al. Blue laser light inhibits biofilm formation in vitro and in vivo by 
inducing oxidative stress. Biofilms Microbiomes. 2019;5(1):1-11.

18. Dai T, Gupta A, Murray CK, Vrahas MS, Tegos GP, Hamblin MR. Blue light for infectious diseases: Propionibacterium acnes, Helicobacter pylori, and beyond? Drug Resistance Updates. 2012 Aug 1;15(4):223-36.

19. Dai T, Wang Y. Antimicrobial blue light: a drug-free approach for inactivating pathogenic microbes. 2018:18.

20. Wang Y, Dai T, Gu Y. Antimicrobial blue light inactivation of Neisseria gonorrhoeae. 2018:23.

21. Wang $Y$, Ferrer-Espada R, Baglo $Y$, Gu Y, Dai T. Antimicrobial Blue Light Inactivation of Neisseria gonorrhoeae: Roles of Wavelength, Endogenous Photosensitizer, Oxygen, and Reactive Oxygen Species. Lasers Surg Med. 2019;51(9):815-23.

22. Wang $Y$, Ferrer-Espada R, Baglo $Y$, Goh XS, Held KD, Grad YH, et al. Photo-inactivation of Neisseria gonorrhoeae: A paradigm changing approach for combating antibioticresistant gonococcal infection. Oxford Univ Press Infect Dis Soc Am. 2019;2-32.

23. Wasson CJ, Zourelias JL, Aardsma NA, Eells JT, Ganger MT, Schober $\mathrm{JM}$, et al. Inhibitory effects of $405 \mathrm{~nm}$ irradiation on Chlamydia trachomatis growth and characterization of the ensuing inflammatory response in HeLa cells. BMC Microbiol. 2012;12.

24. Maclean M, McKenzie K, Anderson JG, Gettinby G, MacGregor SJ. 405 $\mathrm{nm}$ light technology for the inactivation of pathogens and its potential role for environmental disinfection and infection control. Journal of Hospital Infection. 2014 Sep 1;88(1):1-1.

25. Ferrer-Espada R, Wang Y, Goh XS, Dai T. Antimicrobial blue light inactivation of microbial isolates in biofilms. Lasers in surgery and medicine. 2020 Jun;52(5):472-8.

26. Kingsley JD, Demchak T, Mathis R. Low-level laser therapy as a treatment for chronic pain. Frontiers in physiology. 2014 Aug 19;5:306. 